\title{
The Instrumentalization of Fictional Narrative in Relation to Architecture-Urban Environment: The Example of "Laughable Places" Workshop
}

\author{
Merve Eflatun (1) \\ Gebze Technical University, Faculty of Architecture, Department of Architecture, Kocaeli Turkey
}

Received: November 4th 2021, Revised: December 6th 2021, Accepted: December 13th 2021.

Refer: Eflatun, M., (2021), The Instrumentalization of Fictional Narrative in Relation to Architecture-Urban Environment: The Example of

"Laughable Places" Workshop, Journal of Design Studio, V.3, N.2, pp 223-235,

M. Eflatun ORCID: 0000-0002-5529-3918

DOI: $10.46474 /$ jds.1020244 https://doi.org/10.46474/jds.1020244

\begin{abstract}
Interdisciplinary approaches and distinctive representation methods are needed to expand the range of meaning in the architecture and to consider the design process in unique frameworks. Literature disrupts the static images produced for the city in the context of the imaginative weight and the various dynamics it makes with the reader also uses the city, space, and architecture to create a different dimension of representation. This situation, which is inspected in the article regarding the relationship between literature, city, and architecture, will be examined through the "Laughable Places" workshop, that is part of the e-workshop days held at Gebze Technical University in February 2021. In this sense, firstly the relationship between literature and architecture and the revealing of their potentials are handled through the imaginative, representational and textual dimensions. Than through various workshops where the relationship between fictional narrative and architecture is applied, it is reviewed in which contexts fictional narrative can be included in the intellectual process of design. This review has been grouped according to the method in the workshop setups, using the fictional narrative based on literary works or the writing fictional narratives by participants. The workshop process was interpreted through the hybridity of the two approaches.
\end{abstract}

Keywords: Literature, Architecture, Creativity, Workshop, Representation, Design

\begin{abstract}
1.Introduction
Interdisciplinary approaches have an increasingly integral place in the understanding of architecture and the design process. Various approaches provide the opportunity to read the ontology and epistemology of architecture in new frameworks, as well as recognize new areas by creating peculiar contexts in the design process. Main aim of this article to evaluate the effect of fictional narrative, which generally constitutes the nature of literature, on the perception of architecture and the city, through various interdisciplinary workshops held in this context.
\end{abstract}

Literature, which transports the nature of fictional narrative, can be evaluated as a discipline that approaches architecture, architectural design, and the city in assertive contexts. However, it sticks in the mind that it is a field that differs from architecture. It can produce the potential to create new contributions by feeding off this separation and convergence. In this sense, it can be thought of the fictional universe as a cultural product that tries to reflect the environment in that the universe is predominantly located, on the contrary, it might be thought that architecture 
has a closer relationship with situations that reveal concreteness.

It is possible to say that another situation that brings fictional narratives closer to architecture and enables us to think together is the dimension of the city/architecture that is prone to produce a narrative. Leach (2002) states that human-oriented solutions such as structure, park, and transportation networks that emerge by creating a relationship with the place in the city compose more meanings than they show and need rooted powers than those that appear on the surface (p.2). Graham Livesey (2004) points out that the lives created individually or collectively can be structured as a narrative. He says that since the human touch of architecture and the city is revealed through the acts of construction, settlement, and interpretation it will be possible to look at it from the perspective we look at the narrative (p.33). Barthes (1986), on the other hand, emphasizes that the narrative dimension of the city is unfolded by the coexistence of visible and invisible elements. He likens the narrative of the city to a poem that is consistently transforming and can be read in different ways, without any center or theme. De Certeau (2008) uses similar expressions and likens the city to a story.

Thus, it becomes possible to talk about the existence of a narrative dimension that associates fiction with architecture. While the narrative character of literature has a fictional structure that progresses through "fiction" and has the opportunity to be re-evaluated with the reader, the narrative character of the city is abstract and can be reproduced many times by those who experience the city or architecture, and it can be translated into a literary genre by metaphorizing the mere existence of the city.

The article problematizes the practices of fictional narrative on architectural workshops through the workshop titled "Laughable Places" held at Gebze Technical University on February 19-20-21, 2021. After the literature review, the article exemplifies the studies in different scales in which "fictional narrative" is used and read the workshop, which was made by discussing, positioning it according to these studies. It evaluates the relations produced by the fictional narrative with architecture, and the workshops made in the light of these, through the titles of literary fictions and original fictions. The workshop, on the other hand, discusses the hybridity of the two approaches. The methodology in the workshop keeps the fictional narrative both readable and re-evaluable through what is read. In this sense, various stories were read and brought together to form a new fiction based on essential elements such as subject, place, and temporality that make up the fiction. Additionally, it figures out the relationship between the fictional narrative and architecture as design, representation, and narrative.

\section{Relationship Between Architecture and Fictional Narrative}

The word narrative, which comes from the root to narrate, expresses the situation in which one or more. Also, real or unreal events are told with at least one narrator (Prince, 2003, p.58). The narrative is defined by Ricoeur (1984) as a discourse of the narrator describing the discourse of character, arguing that this stems from the human need to give meaning to things naturally. The program that we listen to, a meeting with friends, myths, and historical processes can be included in the narrative (Fludernik, 2009, pp. 1-2). At the same time, performative arts, cartoons that added text can be comprised in different forms of expression that have the potential to be visual and auditory (Chatman, 2008, p.25). Fictional narrative, on the other hand, is a narrative approach that has the characteristics of narrative. Nonetheless, it is debated whether is the relationship with the actual world is imitation or an imitation due to fiction of it (Ricoeur, 1979).

The state of being fictional, which is also a part of literature, in other words, the fictional narrative is an occupation that has spread over a long period. Again, in this sense, it is possible to say that fiction has a structure that is different from everyday language. We do not look for word games, style, or a second meaning in the ordinary narrative that 
conveys any event. Similarly, even if fiction contains a narrative reality, there is fiction (Eagleton, 2015, p.130). Meanwhile, literature, which has fiction, uses it and another tool that defines it, using different ways such as the rhythm, sound, narrative technique of the language, and it distinguishes literature from everyday speech (Eagleton, 1996, p.2). Therefore, it seems necessary to describe the literature as a narrative, perhaps a new act of construction. It can be considered the creative focus like fiction, which is a narrative about everything, or the emergence of a literary work as a flexible phenomenon that can be considered in different environments. In the fictional narrative author has the opportunity to discuss language, fiction, narrative structure, one-to-one communication with the reader, and discussion both within and outside the field through its reproducible construction.

Herewith, it may be evaluated fictional narrative as a tool that can fuel originality or creativity in architectural design because it allows seeing known physical spaces differently. Because quest of literature for concreteness does not have to explain the world we live in as it is, thanks to its progress only through literary representation. Contrarily, the act of writing has the potential to hide and reveal meanings at will, as well as informs many contradictory situations (Grafe et al., 2006). Charley (2012) draws attention to the possibility of using literature, which includes fictional narratives, in research on design history. He mentions that looking at what historical movements that can be read with the changes in the form and structure of the language have changed in the course of both literature and architecture will allow different readings. Furthermore, he states that literature can enrich our understanding of the place and promises more than what an architectural guide to the city can deliver (Charley, 2012, p.1-3; Kimber, 2010, p.70).

"The Poetics of Space" that one of the noteworthy books of Gaston Bachelard, has a cult place in architectural literature, can be given as an example of the fertile field created by the fictional narrative. Bachelard (1996) states in the book that space can not be read-only with its physical values, but peculiar definitions can be produced as it is experienced. In this context, he uses novelists and poets such as Bocho, Rilke, Baudelaire to reveal the different meanings of home. Also, the relationship between language use of literature and fiction and the city has a meaningful place in the way of thinking of architecture. For instance, Graham Livesey (1994) expresses that the relationship between architecture and fiction constitutes the preoccupation of architects such as Peter Eisenman, Bernard Tschumi, and Nigel Coates, and the affiliation between fiction and architecture investigated in various ways. These can be realized by incorporating the narrative or narrative structure of the architect into the process, by creating a backdrop that allows new narratives of an architectural act in the city (it can be an architectural work or a piece of the city), or by transforming it into concrete architectural products through architecture, memory or allusion.

Diversely, a fictional narrative is contemplated as a forceful resource in the design process, rather than just a better understanding of the city/architecture or characterizing it as an original guide. Gomez (2012) states that when literary language is approached phenomenologically, it has a poetic, origin and multiple meanings. Therefore it can help to find cultural resources in the atmospheric expression of architecture. We can think of literature as a rich source of insight, and this is the case that puts it beyond a scientific map or percentile calculations. The fact that the novel is a simple narrative form used all over the world will help the architect to understand other cultures and lives also developing a sense of empathy in design (pp. 179-188). Havik (2018), on the other hand, imports that the literary language will help us better understand the complexity of architectural experience as well as familiar architectural tools such as maps and plan sections in the sense of atmosphere (p. 271). To deduce that experiencing the novel has an influence on the design process of the architect in terms of 
understanding the human being is described as a generalized value of literature. The crucial part is that this whole set of values produced by literature, both the slippery state of the literary space with the non-concrete potential and the position of the reader open to the imagination in their experience.

Even though the fictional narrative is marked in an exact place, it is continued by the reader on a spatial basis. For the spatial possibilities of fiction, frames defined by Ruth Ronen (1986) play an operative role in the conception of architecture in reflection. According to Ronen (1986), space intervenes in certain frames in fiction. It should be evaluated by a material dimension that will be followed indirectly apart from the text. Spatial productions are carried out in various variations in a situation that is integrated with the character and the event. Likewise, Mikhail Bakhtin (1981), who was one of the first to think properly in a way, will also be the subject of chronotope. All that is shown in the time, place, and calendar from time of "crono" may come together as necessary and whole. In the chronotope, which considers time as a concept that can thicken, time can be seen as it accumulates. The place is also treated as a story, historical and progressive force (Bakhtin, p. 84). In this sense, the space of fiction, the spatial design of architecture can be dull and otherwise transformed. But here, fiction of reader and author is a complex link, like a region that expands the fictional space in the frame.

"The death of the author" that the thought of Roland Barthes also points out to this situation. Barthes (2018) says that when it is looked at the text-only from the perspective of the author opens up to a single meaning, and as the number of readers reading and interpreting the text increases, the text will have the chance to be rewritten many times. Do not assume a position that aims to explain everything about the universe in which the fictional narrative is formed; the fact that a narrative in which everything is told has the potential to extend indefinitely allows the reader to move forward by filling in the gaps. The fact that the narrative expects from the reader (Eco, 1995, p. 9). Hereby, the thought of the fictional narrative can act as a mediator in the understanding of architecture and the city in the design process is possible to say. At the same time, a fictional narrative is observed as a potential value that can provide interdisciplinarity in the design process and feed the design process.

\section{Fictional Narrative as a Tool of Architectural Design Process}

The rapid increase in the scope of knowledge in the twentieth century reveals that cultures with a disciplinary approach and perspectives that draw borders are not inclusive of different forms of inquiry and explanations. With this increase in knowledge reminding the importance of interdisciplinary approaches, it is mentioned that many of the academics who implement the approach are more courageous in their ideas and are more inclined to transcend traditional knowledge patterns (Lattuca, 2001, pp.2-3). As a nostalgia aimed at the integrity of interdisciplinary circles in knowledge, it engages in extensive, comprehensive, disciplined exemplary practices integrated with this society; creating knowledge on small scales (Klein, 1990, pp. 11-12). Interdisciplinary approaches are becoming a frequently used phenomenon both in design history and in design itself (Walker, 2009 , p. 47). Besides the narrative is a focus of discussion about what is architectural. The interrogation of different disciplines and nations after the architecture of the 1960s is observed extensively through narratives of space and literary narratives (Nesbitt, 1996, p. 17). Likewise, Kristeva (1980) states that the transformation in the $60 \mathrm{~s}$ had a profound impact on theoretical approaches. With pieces of training in these narrative design studios against language, teachings, the question of "fiction" is questioned.

Herewith, it is revealed that the narrative is being used in various ways in the design process of architectural education. The narrative is used informally in the education process, but the resource of the narrative itself is not sufficiently used. Hence, it is suggested 
that the narrative can be structured in various contexts and used in the process: The ways of this can be done by narrating the lives of famous architects, constructing an architectural story, exercising the sense of space or place in the story and concretizing these spaces (Nazidizaji et al., 2015). Thinking in the context of narrative as a concept of design; it is mentioned that it can offer a different perspective to the designer in conventional design processes (Gerards \& De Bleeckere, 2014). Erickson (1996), on the other hand, says that working as a storyteller is an exceptional tool for understanding the point of view of the user. One of the problem- solving activities approached with various linear methods of approach to design through narrative; It carries a non-linear puzzle solution that thinks about complexity into activity (Çelik \& Aydınlı, 2008).

It is possible to observe the attempts of the integration of the narrative of fiction into workshop processes in different ways. Within the scope of the article, it reminds the possibility of the workshop experiences, in which the fictional narrative is included, the opportunity of the narrative infiltrating everywhere, becoming fiction, and turning it into an architectural representation. It is noticed that the fictional narrative is mainly considered in two different ways in these workshop processes. One of them is the fact that the ready-made fictional narrative enriches the design process. This approach is realized both through an urban or spatial pattern that is absolute or as a part of any design process that is fictional. Another method is to expect the participants to create a fictional narrative in the content of the workshop process. It may be said that in this approach, where the direction predominates of designer, concrete spaces are predominantly used.

\subsection{Using Literary Works in a Design Process}

It is remarked that the formats of the fictional narrative, which have become literary works written by the author, are transformed into a tool that will form a source in various workshop processes or the concreteness of architecture. For example, the application style of "The Laboratory of Literary Architecture" mostly works on producing space fiction by metaphorizing the narrative pattern in fiction.

They consider the narrative dimension of architecture and the architectural dimension of the narrative in the laboratory environment. To illustrate, workshop participants Joss Lake and Stephanie Jones produced a space setup based on both the narrative and the logic of the novel, in the space that was created based on novel "The Rings of Saturn" by W.G. Sebald (2006) (Fig.1). They think that the long and narrow nature of the space reflects the sincerity

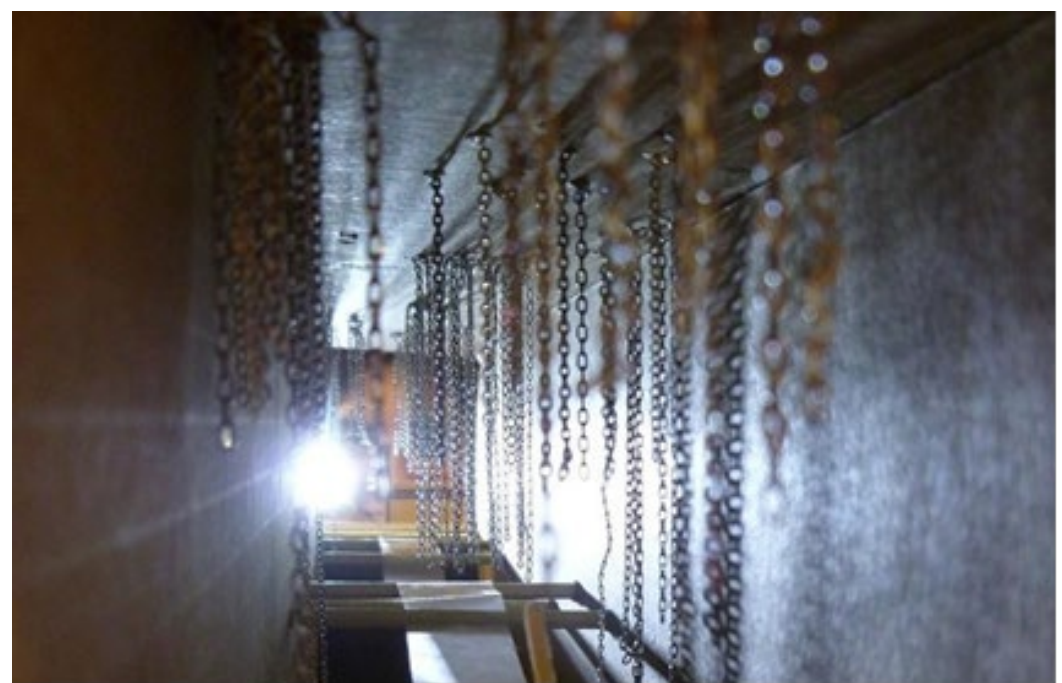

Figure 1: Model produced by Joss Lake and Stephanie Jones based on the novel "The Rings of Saturn" (Source: The Laboratory of Literaty Achitecture) 
of reading, and they associate the gradual rise of the road with the surprising nature of the novel. It is thought that light bulbs as details that the character in "The Rings of Saturn" uses to save the past. This suggests that a novel is a metaphorical approach that fuels creativity rather than a direct copyist approach while creating space fiction (The Laboratory of Literaty Achitecture, n.d.).

In the workshop organized by Argus and Writingplace (n.d.), literary methods were used to reveal the narrative features of the designs. Examples of work carried out in the workshop are a poem about a raindrop falling on a building or a monologue on a forgotten statue in Bogota. The study that was made in the basic design course at Yildiz Technical University is on the reflection of the images formed in the mind through literature. For this purpose, the black and white section was chosen from Istanbul Memories and the City by Orhan Pamuk (2006). After the text reading, an image was focused and texture was produced. The aim of the study is how the same text can evoke different images in the mind (Bekdaş, 2018). The studio carried out in Bahçeşehir University Interior Architecture Class 1 is about to use the poems of Edgar Allan Poe. It aims to make inferences about space and atmosphere through poems of Poe. As a result, it is possible to say that the discovery of the atmosphere is realized through literature (Gülmez et al., 2020).

Ultav and Hasirc1, differently, were expected to create atmospheres for the homes of various poets such as Gülten Akın, Edip Cansever, and Atilla İlhan in their studio work. For this, it is expected to produce a space atmosphere by making use of both the narratives of the lives of poets and their poems. An interpretation is generated by using concrete and abstract metaphors inspired by both poetry and life story. As an example of this, he uses the semiotic potential of the mirror reflecting life and emulating the life of the mirror, which is the representation of poem of Cemal Süreya "Kan Var Bütün Kelimelerin Altında" (There is blood beneath whole words) (Hasirc1 \& Ultav, 2012).
Reflecting from the fictional to the space design through various perspectives, and the search for the creative effect, as well as transformability of it into concrete architectural products in the literary work, generates a discussion. It can be said that there is an emphasis on considering fictional narratives as a new tool that enriches and triggers the world of thought and provides a different perspective on the design process.

\subsection{Writing Fictional Narratives by Participants}

Fictional narrative can provide a dynamic that allows participants to rewrite the city/architecture by making use of the fact that the city has narrative. The workshop titled "Narrative Architecture" has a structure that stands out from the fictional narrative. It is about the interpretation and narrativization of place. Yet the place is completely narrated and transferred on the mapping of the story. Afterward, the design process is narrated and the story of the place overlaps with the collage method. Therefore, "Narrative Architecture" has an exceptional fictional ground (Narrative Architecture, 2019). In the workshop titled "Street in Narrative-Kuwait City" participants experienced some buildings in Mubarak Al Kabeet Street and produced stories based on these experiences. It is noticeable to experience the city and the street with a new eye through the character, space, and scenario. Instead of focusing on a representation as it is, the participants were expected to produce experience diagrams and collages. Involvement of the generated characters in the space. Again in the workshop "In NarrativeManama", a similar workshop setup was made for "Manama" this time. "Writing Architecture Through Fiction" (n.d.), organized at MIT, brings together the imaginative dimension of architecture with fiction. Transforming fictional writing into clear-sighted architectural dreams is the main path in the workshop. The historical and theoretical issues involved in the design process are conveyed through narrative architecture. Participants can narrate both the process and the design produced at the same time. In the workshop experience conducted by 
Funda Uz (2007), the names of various places in Taşkışla are kept secret and they are expected to describe them through literary methods or models. As a result, the comparison of the reality of the place with the narrative or the similarities in the textual transmission were examined. Contrary to the examples in which literary works are used, it can be said that there is a reverse translation towards the fictional narrative in these workshops.

\section{Laughable Places as a Hybrid Narrative Workshop Experience}

"Laughable Places" is a workshop held on 19, 20, 21 February 2021 as part of Gebze Technical University e-workshop days conducted by Merve Eflatun. The reason that the name of the workshop is named "Laughable Places" is because it is predicted that the new stories and story spaces that will be formed due to the decomposition and then reassembly of different fictional narratives will contain. It is aimed to add the diversity of relationships produced by the reader to the relationship between text, architecture, and language. The fact that the reader also reproduces the story is an important point here. What is waited from the reader is to fill and represent the gap between the different fictional worlds in an integrated manner with his own architectural and narrative description. While doing this, it is expected to create additional events and produce the narrative. The reader who writes the story transfers his story to another reader to represent it. Thus, the practice of both writing a spatial narrative and analyzing another spatial narrative may be accepted as the main tasks (Figure 2). In the workshop process, literature is both a tool to enrich spatial perception and a kind of decoupage object of the design process as individual narratives are created by breaking up literary stories. The literary narratives in question were grouped into various stories depending on the space, subject, and time factor, and the participants were allowed to choose freely, provided that they chose from each group.

This grouping plans to comprehend the importance of factors such as space, time, and subject in the narrative, both in fiction and in architecture, and to ensure that different focuses on a narrative are perceived. In the title of the place, there are

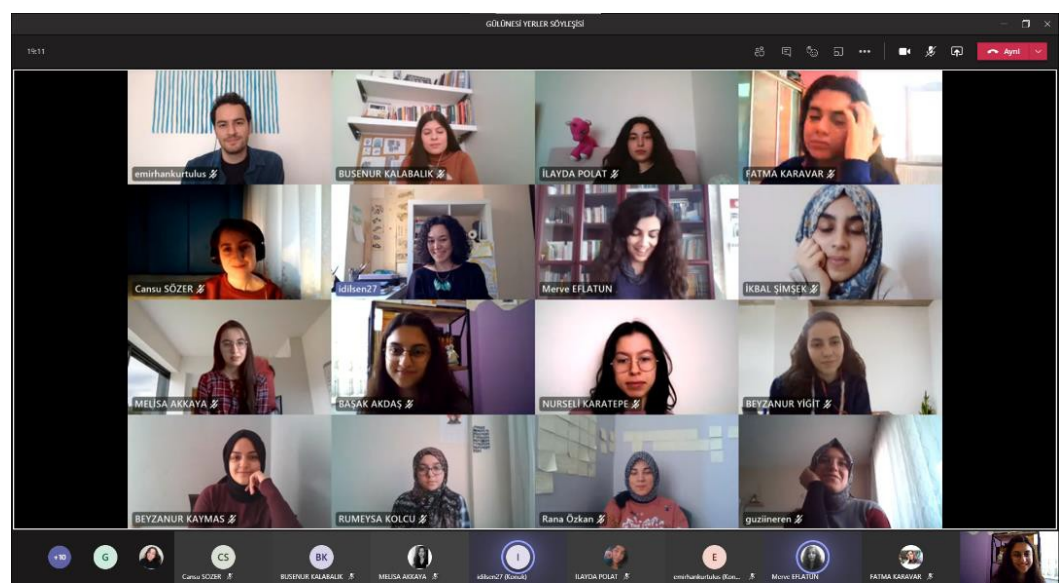

Figure 2: "Laughable Places" workshop (Photo by Başak Akdaş). 
differentiating urban-architecture relations such as a house that can go to various places, a future imagination for the Bosphorus, a Historical Peninsula that was closed as a result of an epidemic in an unknown future date. Narratives of Alan Lightman in the title of time contain different universe imaginations such as people have no memories, time pauses, and human life spans a single day. In the stories in the subject title, the characters such as the poet and depressive brother, whose books have not been published, can be seen as the main theme of the fiction. At the same time, there are stories of cult authors such as Ernest Hemingway and Gogol, which include characters with different personality additionally with some extraordinary life stories such as Simon Sigmar and Aurelio Quattrochi (Table I).

Table 1. Stories that used in workshop process

\begin{tabular}{|c|c|c|}
\hline Space/Place & Time & Subject \\
\hline $\begin{array}{l}\text { Author: Dino Buzzati-Book: "Tanrlyl } \\
\text { Gören Köpek" (The Dog Who Saw } \\
\text { God) / Chosen Story: "Büyük Otel } \\
\text { Koridoru”, (Grand Hotel Corridor) }\end{array}$ & $\begin{array}{l}\text { Author: Alan Lightman-Book: } \\
\text { "Einstein'in Düsleri” (Einstein's } \\
\text { Dreams) / Chosen part: "İnsan } \\
\text { Ömrünün Tek Gün Sürdügü Dünya", } \\
\text { (In this world in which a human life) } \\
\text { spans but a single day) }\end{array}$ & $\begin{array}{l}\text { Author: C. D. Rose- Book: } \\
\text { "Olamayanlar" (The Biographical } \\
\text { Dictionary of Literary Failure) / Chosen } \\
\text { Story: "Aurelio Quattrochi" }\end{array}$ \\
\hline $\begin{array}{l}\text { Authors: Eduardo Galeano\& Isidro } \\
\text { Ferrer- Book: "Helena 'nın Rüyalart", } \\
\text { (Dreams of Helena)/ Chosen story: } \\
\text { "Kayıp Rüyalar", (Lost Dreams) }\end{array}$ & $\begin{array}{l}\text { Author: Alan Lightman- "Einstein'in } \\
\text { Düssleri" (Einstein's Dreams) / Chosen } \\
\text { Part: "Bu DünyadaInsanların Bellekleri } \\
\text { Yok", (A World Without Memory) }\end{array}$ & $\begin{array}{l}\text { Author: C.D.Rose Book: } \\
\text { "Olamayanlar" (The Biographical } \\
\text { Dictionary of Literary Failure) / Chosen } \\
\text { Story: "Simon Sigmar" }\end{array}$ \\
\hline $\begin{array}{l}\text { Author: Eduardo Galeano \& Isidro } \\
\text { Ferrer- Book: "Helena'nın Rüyalarl", } \\
\text { (Dreams of Helena) / Chosen story: } \\
\text { "Yolculuk Eden Ev", (Traveling Home) }\end{array}$ & $\begin{array}{l}\text { Author: Alan Lightman “Einstein'in } \\
\text { Düssleri” (Einstein's Dreams) / Chosen } \\
\text { part: "Zamanin Durakladığ Bir } \\
\text { Dünya” (The World Stops) }\end{array}$ & $\begin{array}{l}\text { Author: Ernest Hemingway Chosen } \\
\text { Story: "Kilimanjaro'nun Karları" } \\
\text { (The Snows of Kilimanjaro) }\end{array}$ \\
\hline $\begin{array}{l}\text { Editor: Kutlukhan Kutlu, Author: Engin } \\
\text { Türkgeldi-Book: "Istanbul 2099"/ } \\
\text { Chosen story: "- "Sur", (Wall) }\end{array}$ & & $\begin{array}{l}\text { Author: Nikolai Gogol-Chosen Story: } \\
\text { "Burun" (Nose) }\end{array}$ \\
\hline $\begin{array}{l}\text { Author: Faruk Ulay- "Beldeler } \\
\text { Kitabl"(The Book of Towns) / } \\
\text { "Kullanllmayan Nesneler Beldesi", } \\
\text { (Town of Unused Objects) }\end{array}$ & & $\begin{array}{l}\text { Author: Mevsim Yenice-Book: } \\
\text { "Bilinmeyen Sular" (Unknown Waters) }\end{array}$ \\
\hline $\begin{array}{l}\text { Author: Faruk Ulay-Book: } \\
\text { "BeldelerKitabl" (The Book of Towns) } \\
\text { / Chosen Story: "Yıkllmış } \\
\text { Uygarliklardan Arta Kalan Nesneler } \\
\text { Beldesi", (Land of Remains of Ruined } \\
\text { Civilization) }\end{array}$ & & $\begin{array}{l}\text { Author: Samantha } \\
\text { "Ağızdaki Kuşlar" (Mouthful of Birds / } \\
\text { Chosen Story: "Kardeşim Walter" (My } \\
\text { Brother Walter) }\end{array}$ \\
\hline $\begin{array}{l}\text { Author: HP Lovecraft- Chosen Book: } \\
\text { "Deliliğin Dağlarında" (In the } \\
\text { Mountain of Madness) }\end{array}$ & & \\
\hline $\begin{array}{l}\text { Author: Orhan Pamuk- Book: "Kara } \\
\text { Kitap" (Black Book) / Chosen Part } \\
\text { "Boğazın SularıÇekildiği Zaman" } \\
\text { (When the Bosphorus Dries Up) }\end{array}$ & & \\
\hline $\begin{array}{l}\text { Author: Sait Faik Abasiyanık- Book: } \\
\text { "Alemdağ'da Var Bir Yilan" (A Snake } \\
\text { in Alemdağ)/ Chosen Story: } \\
\text { "Dolapdere" }\end{array}$ & & \\
\hline $\begin{array}{l}\text { Author: Gonçalo M. Tavares- Book: } \\
\text { "Beyefendiler" (The Neighborhood) } \\
\text { /Chosen Part: "Balon”, (Baloon) }\end{array}$ & & \\
\hline
\end{tabular}


The participants were divided into seven groups, fragmented various stories, brought them together with their own persontime/space-plot, and created new stories. It is possible to say that the stories constitute an example of collage in this sense. The purpose of the formation of the stories in this way is to reveal new potentials by playing with the time-space axis in the stories. For instance, "house", which is the subject of the story "The Traveling House", becomes a vehicle that the main character in "My Brother Walter" takes everywhere; the ninthdegree officer in "The Nose" story of Gogol takes part in an epidemic in Istanbul where everyone lost their nose; Harry, the main character of The Mountains of Kilimanjaro, travels to the Istanbul of the Black Book by reading his memoir.

When the stories were transferred to different groups, the groups were confronted with narratives that it can be considered partially foreign to them. At this stage, the groups represented the narratives on the axis of space-person-time (Figure 3). Here, the participants divided the newly written narrative into various sequences and used different representation scales such as collage, drawing, and model (Figure 4).

Although it may be considered the fictional narratives created by the participants as original structures due to their productions, there have been cases where they used similar pieces from various fictions. This situation has an noticiable place in the workshop process in the perception of different perspectives and the production of empathy in the triangle of representation, city-human relationship, and narrative. For example, exact passages were used by different groups in the "When The Bosphorus Dries Up" part in Black Book by Orhan Pamuk, but due to the differences in the theme of the narrative, the similar space definition found very different atmospheric expressions. Sometimes it was caricatured, and sometimes it was able to integrate more with the subject in the fiction (Figure 5).
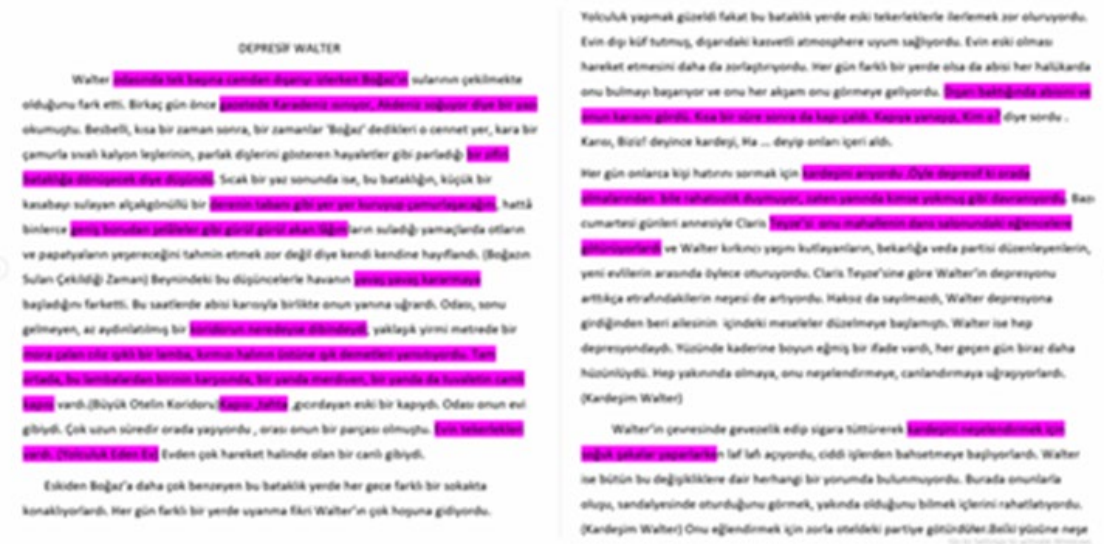

Figure 3: The process of stories that splitted up and invention of new stories (Story made by Beyzanur Kaymas and Rumeysa Kolcu). 

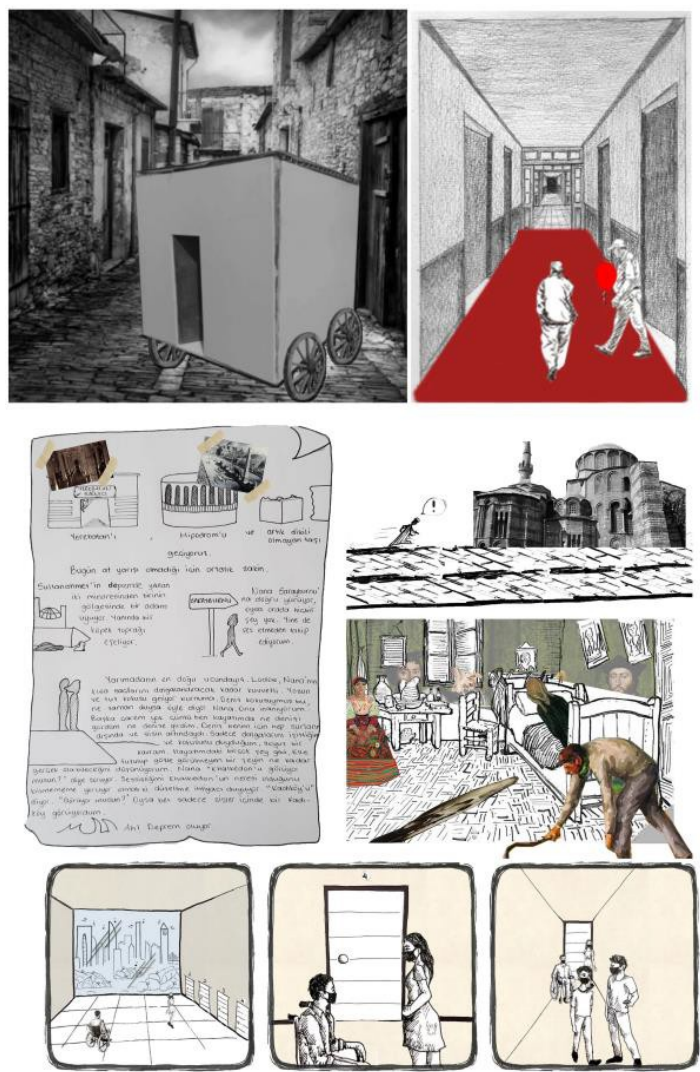

Figure 4: Different representation techniques for discovering the relationship between space/time, subject ( Images made by Başak Akdaş, Melisa Akkaya, Beyzanur Yiğit, İkbal Şimşek, Rumeysa Kolcu, Busenur Kalabalı, Güzin Eren, Nurseli Karatepe, Rana Özkan).

The workshop participants have the opportunity to experience the relationship between fiction and architecture, with their productions, on two separate faces. The first of these is to use the literary one as a design tool and to complete it and turn it into a new design product, in other words, to evaluate a language-shaped phenomenon with the practices of architecture, and the second is to investigate the spatial equivalents of a fictional text with the eyes of the variable reader, and to help the reader both in the narrativity of the city/architecture and also realizes the potential of producing new writings over and over again in the representational dimension of the literary. It reminds us that the literary product itself is a design and the importance of language and expression. The workshop process can be

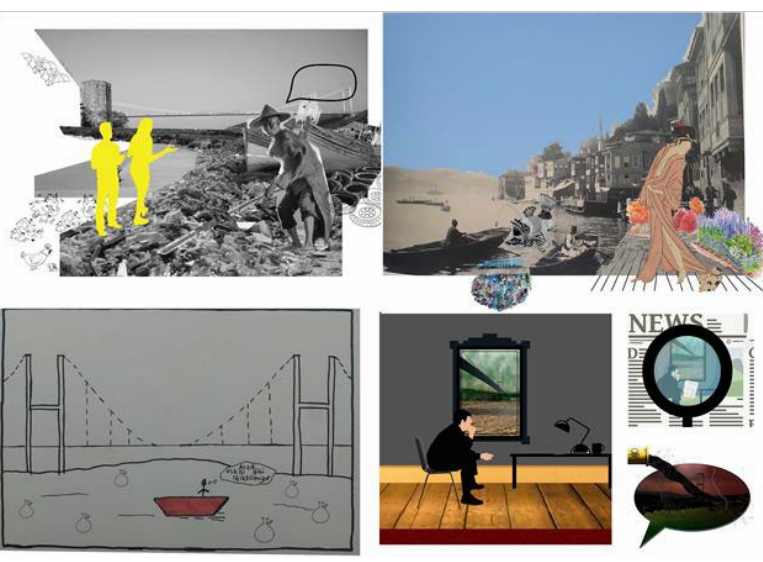

Figure 5: The flexible representation of Bosphorus depending on the narrative atmosphere and participants (Images made by Cansu Sözer, Illayda Polat, Busenur Kalabalı, Güzin Eren, Beyzanur Yiğit, İkbal Şimşek, Başak Akdaş, Melisa Akkaya).

described as a hybrid fiction in the sense that it both benefits from literary works and leaves a gap in producing fiction of one in the context of the relations it outcomes with it.

\section{Discussion and Conclusion}

It can be regarded as a fictional narrative as an expressive tool in the examination of the relationship between architecture and the city. It is understood that the workshops, which are written by the participant occasionally and sometimes open to discussion about the use of fictional narrative. The guide in creating an architectural practice through literary works can be both a mind-opening exercise in developing spatial practice and a convenient resource in non-architectural practices in terms of understanding the spatial nature of fiction. When the relationship between fictional narrative and architecture is evaluated with different combinations such as the structure of the text, plot, subject, time, rather than reading that will be carried out only by filtering the space, it becomes possible to read it as a "design process" that is opened to re-evaluation with the reader. It is noticed that the "Laughable Places" workshop not only strengthens the reader-writer relationship by processing the fictional narrative itself but also that the representation through fiction can lead to the discovery of new contexts. From 
the perspective of the participants, the gap between the literary representation and the visual representation and the differing viewpoints according to the reader formed an important focus. They observed that reconstructing the texts and rendering them functional, rather than the one-to-one transfer of the architectural descriptions in the texts, provides different and new observation possibilities for the relationship between the text and the architecture. Participants stated that writing a text that contains both fictional and architectural content at the beginning differs from the conventional architectural representation. It was thought that it may be a critical approach to think about the relationship between architecture and the city in the narrative dimension. The use of literary and visual representation together can be contemplated both as a threshold to increase creativity in the design process and as a tool that can break the overhead view and expanded empathy in design.

\section{Acknowledgement}

This article was written within the scope of the "Theoretical Studies in Design" course conducted by Prof. Dr. Şebnem Timur at Istanbul Technical University. The workshop participants Nurseli Karatepe, Başak Akdaş, İlayda Polat, Beyzanur Yiğit, İkbal Şimşek, Beyzanur Kaymas, Güzin Eren, Fatma Karavar, Melisa Akkaya, Rumeysa Kolcu, Rana Özkan, Busenur Kalabalık and Cansu Sözer, who have a share in the theme of the article, thanks for your hardwork.

\section{References}

Argus x Writing Place:Space Time/Narrative. (n.d.). ARGUS. Retrieved April 15, 2021, from

https://www.argus.cc/argus- $\quad \mathrm{x}$-writingplacespace- $\% \mathrm{C} 2 \% \mathrm{~B} 1$-time-narrative/.

Bachelard, G. (1996). Mekanın poetikası. İstanbul: Kesit.

Bakhtin, M. M. (1981). The dialogic imaginations: four essays. Austin, Texas: Texas University Press.
Barthes, R. (1986) Semiology and the Urban. In M. Gottdiener and A. Lagopoulos (Eds.). The City and The Sign: An Introduction to Urban Semiotics (pp. 87-98). New York : Columbia University Press.

Barthes, R. (2018). Yazarın Ölümü. Retrieved April 15, 2021, from

https://oggito.com/icerikler/yazarinolumu/8913

Bekdaş, H. D. (2018). Conceptual thinking at the intersection of art and design: Informal education studies (2009- 2015). Megaron / Yildız Technical University, Faculty of Architecture E-Journal, 13(2), 324-333.

Charley, J. (2012). The Routledge Companion on Architecture, Literature and The City. London: Routledge.

Chatman, S. B. (2009). Öykü ve Söylem: Filmde ve Kurmacada Anlatı Yapısı. Ankara: De Ki.

Celik, P. Y., \& Aydinli, Y. (2007). Creativity in design education: From problem-solving to puzzle-solving. ITU $A \mid Z, 4(2), 38-51$.

De Certeau, M. (2008). Gündelik Hayatın Keşfi. Ankara: Dost Kitabevi Yayınları.

Eagleton, T. (1996). Literary Theory: An Introduction. Oxford: Blackwell.

Eagleton, T. (2015). Edebiyat Nasil Okunur. İstanbul: İletişim.

Eco, U. (1995). Anlatı Ormanlarinda Altı Gezinti: Deneme. İstanbul: Can Yayınları.

Fludernik, M. (2009). An Introduction to Narratology. London: Routledge.

Gerards, S., \& De Bleeckere, S. (2014). Narrative Thinking in Architectural Education. ARCC Conference Repository.

Grafe, C., Havik, K. \& Maaskant, M. (2006). Architecture \& Literature, Reflections / Imaginations. Oase,70, 3-7. 
Gülmez, N. Ü., Yağan, D. A., Güney, E. E., \& Şahin, M. (2020). Staging Poe: A narrative approach to Atmosphere in a first-Year design studio. Journal of Interior Design, 45(4), 11-32.

Hasirci, D., \& Ultav, Z. T. (2012). An Interdisciplinary approach to the design studio: Poetry as a Complementary Feature to the Creative Process. Procedia - Social and Behavioral Sciences, 51, 618-634.

Havik, K. (2018). Writing atmospheres: Literary methods to investigate the thresholds of architectural experience. In J. Charley (Ed.). The Routledge Companion on Architecture, Literature and the City (pp.270283). London: Routledge.

Kimber, L. (2010). Truth in Fiction: Storytelling and Architecture [Master thesis, Victoria University]. Victoria University of Wellington, School of Architecture.

Klein, J. (1990). Interdisciplinarity: History, Theory, and Practice. Detroit: Wayne State University Press.

Kristeva, J. (1980). Desire in Language. New York: Columbia University Press.

Laboratory of Literary Architecture. (n.d.). LabLitArch. Retrieved April 26, 2021, from http://lablitarch.com/.

Lattuca, L. R. (2001). Creating interdisciplinarity: Interdisciplinary research and teaching Among. College and University Faculty. Nashville: Vanderbilt University Press.

Leach, N. (2002). The Hieroglyphics of Space: Reading and Experiencing the Modern Metropolis. London: Routledge.

Livesey, G. (1994). Fictional cities. In PérezGómez, A. and S. Parcell (Eds.). Chora 1: Intervals in the Philosophy of Architecture (pp. 109-122). Montréal: McGill-Queen's University Press.
Livesey, G. (2004). Passages: Explorations of the Contemporary City. Calgary: University of Calgary Press.

Nazidizaji, S., Tome, A., Regateiro, F., \& Ghalati, A. K. (2015). Narrative ways of architecture education: A case study. Procedia - Social and Behavioral Sciences, 197, 1640-1646.

https://doi.org/10.1016/j.sbspro.2015.07.213

Narrative Architecture. (2019,March 21). Archiford. Retrieved April 16, 2021, from

https://www.archiford.com/2019/03/21/narrat ive- architecture/

Nesbitt, K. (1996). Introduction. In K. Nesbitt (Eds.), Theorizing a New Agenda for Architecture - An Anthology of Architectural Theory 1965-1995. New York: Princeton Architectural Press.

Pamuk, O. (2006). Istanbul: Memories of a City. London: Faber \& Faber.

Perez Gomez, A. (2012). Literary language and architectural meaning. In Charley J. (Eds.). The Routledge Companion on Architecture, Aiterature and the City (pp. 179-190). London: Routledge.

Prince, G. (2003). A Dictionary of Narratology. Lincoln, NE: University of Nebraska Press.

Ricoeur, P. (1979). The Human Experience of Time and Narrative. Brill. 9, 17-34.

Ricoeur, P. (1984). Time and Narrative Vol. 1. Chicago \& London: University of Chicago Press.

Ronen, R. (1986). Space in fiction. Poetics Today, 7(3). 421-438.

Sebald, W. G. (2006). Satürn'ün Halkaları: Ingiltere'de Bir Hac Yolculuğu. İstanbul: Can Yayınları. 


\section{Journal of \\ Design Studio}

$\mathrm{v}: 3$ n:2 December 2021

Sönmez, F. U. (2007). Mekanın Yazınsallığ1 ve Bir Taşkışla Deneyimi. Arredamento, 200, 53.

The Laboratory of Literary Architecture (n.d.) LabLitArch. Retrieved April 15, 2021 from http://lablitarch.com/

Walker, J. (2009). Defining the object of study. In (H. Clarks and D. Brody Eds.). Design Studies A Reader (pp. 42-49). Oxford, Newyork: Berg.

Writing Architecture Through Fiction (n.d.) Architecture MIT. Retrieved April 15, 2021, from https://architecture.mit.edu/subject/iap2018-iap-non-credit-0 